Marquette University

e-Publications@Marquette

College of Education Faculty Research and

Publications

Education, College of

$8-1-2010$

Female Traditional Principals and Co-Principals: Experiences of Role Conflict and Job Satisfaction

Ellen Eckman

Marquette University, ellen.eckman@marquette.edu

Sheryl Talcott Kelber

University of Wisconsin-Milwaukee

Accepted version. Journal of Educational Change, Vol. 11, No. 3 (August 2010): 205-219. DOI. (C) 2010 Springer. Used with permission. 


\title{
Female Traditional Principals and Co-Principals: Experiences of Role Conflict and Job Satisfaction
}

\author{
Ellen Wexler Eckman \\ College of Education, Marquette University \\ Milwaukee, WI \\ Sheryl Talcott Kelber \\ College of Nursing, University of Wisconsin-Milwaukee \\ Milwaukee, WI
}

This paper presents a secondary analysis of survey data focusing on role conflict and job satisfaction of 102 female principals. Data were collected from 51 female traditional principals and 51 female co-principals. By examining the traditional and co-principal leadership models as experienced by female principals, this paper addresses the impact of the type of leadership model (traditional principalship or co-principalship) has on women principals with regard to role conflict and job satisfaction. The co-principals experienced lower levels of role conflict and higher levels of job satisfaction than did the female traditional principals.

At a time when there is a shortage of qualified applicants for the principalship in schools world-wide, many experienced principals, in particular members of the 'baby boom' generation, are approaching retirement age (DiPaola and Tschannen-Moran 2003; Ferrandino and Tirozzi 2000). There is increasing concern among school superintendents, educational scholars, and policy makers regarding an impending leadership crisis (Association of California School 
Administrators [ACSA] 2001; Educational Research Service 1998; Institute of Educational Leadership [IEL] 2000; National College of School Leadership [NCLS] 2006; Protheroe 2001; Young and McLeod 2001). Many qualified educators are not applying for positions at a rate that will meet the demand for principals, particularly for secondary schools, despite there being a number of licensed and certified principals (Ferrandino and Tirozzi 2000; IEL 2000; NCLS 2006). Those qualified candidates who are unwilling to apply or accept positions as school principals have indicated that their reluctance is due to "the high levels of stress associated with the job; pressures of accountability for student success; insufficient salary; and a lack of time for a personal life" (Chirichello 2003, p. 356). Additionally, there continues to be an underutilization of women in educational administration (Bell and Chase 1993; Grogan 1999; Young and McLeod 2001). Pounder and Merrill (2001b) noted that females earn more than half of the administrative degrees and licenses from educational preparation programs in the United States and are a "potentially large candidate pool" for the principalship. However, Young and McLeod (2001) reported that in the United States only $26 \%$ of secondary school principals are women.

Educational researchers have suggested strategies to attract qualified principal candidates such as: changing the public's expectations for principals, providing more mentoring and encouragement to potential leaders, developing leaders from within a school system, and restructuring the position itself (ACSA 2001; Ferrandino and Tirozzi 2000; Whitaker 2001). Pounder and Merrill (2001a) explain that in order to recruit highly qualified individuals to the principalship ways must be found "to reduce the negative elements of the job while enhancing the positives' (p. 48). This leads to the question of how the role of the principal can be redesigned or restructured so as to reduce the demands and conflicts that make the position seem unattractive to otherwise qualified candidates.

The co-principal leadership model offers one approach to answering that question; it is an alternative model that restructures the principalship, enhancing the positive aspects of the position (Chirichello 2003; Grubb and Flessa 2006). This model has been utilized in schools in Australia (Gronn and Hamilton 2004; Thomson and Blackmore 2006), China (Bunnell 2008), New Zealand (Court 2003), the United Kingdom (Paterson 2006), and the United States

Journal of Educational Change, Vol. 11, No. 3 (August 2010): pg. 205-219. DOI. This article is (C) Springer and permission has been granted for this version to appear in e-Publications@Marquette. Springer does not grant permission for this article to be further copied/distributed or hosted elsewhere without the express permission from Springer. 
(Eckman 2006; Grubb and Flessa 2006; Houston 1998). Although the co-principal model has been implemented, little is known about the model itself, its effectiveness and its sustainability (Eckman 2006; Gronn and Hamilton 2004).

The purpose of this paper is to provide insight into the coprincipalship model by describing the levels of job satisfaction and role conflict for female principals $(N=102)$. By examining the traditional and co-principal leadership models as experienced by female principals, this paper aims to answer these questions: How does the type of leadership model (traditional principalship or co-principalship) impact women principals with regard to role conflict and job satisfaction? Does the co-principal model contribute to lower levels of role conflict and higher levels of job satisfaction for women than the traditional principal model?

\section{Traditional and co-principal models}

The role of the principal has changed markedly from its first historical designation as the "principal teacher" (Matthews and Crow 2003 , p. 18). During the twentieth century, the role of the principal has been "extremely malleable," with successive generations emphasizing different roles for the principal. "During economic depression, principals were expected to be thrifty stewards of limited resources; in time of war, they were expected to mobilize the next generation to defend democracy; amid fears of declining achievement, they were expected to be instructional leaders" (Lashway 2006, p. 27).

Scholars in educational leadership have conceptualized the role of the traditional principal in multiple ways. Leithwood and Duke (1999) identified six role conceptions for the principal: instructional, transformational, moral, participative, managerial, and contingent. Matthews and Crow (2003) defined seven role conceptions for the principal: leader, learner, politician, advocate, manager, supervisor and mentor. Sergiovanni (2001) described the principalship from a "reflective practice perspective." Strike (2005) emphasized the role of the principal as an ethical leader. Others have described the heroic or charismatic principal who is responsible for all the managerial and instructional functions of the role along with providing vision and leadership for the organization and its community (Klenke 1996).

Journal of Educational Change, Vol. 11, No. 3 (August 2010): pg. 205-219. DOI. This article is (C) Springer and permission has been granted for this version to appear in e-Publications@Marquette. Springer does not grant permission for this article to be further copied/distributed or hosted elsewhere without the express permission from Springer. 
The National Association of Secondary School Principals (NASSP) surveys high school principals every 10 years to gather a snapshot of the "typical" high school principal. The report from a recent survey characterized the principalship as a very complex and demanding position. "Today's principal must be a legal expert, health and social services coordinator, fundraiser, public relations consultant, parental involvement expert, and security officer, who is technologically savvy, diplomatic, with top-notch managerial skills, whose most important duty is the implementation of instructional programs, curricula, pedagogical practice, and assessment models" (National Association of Secondary School Principals 2001).

Regardless of how the role of principal is operationalized, the traditional principal has always been the solo leader at the top of the hierarchical organizational structure of the school. The complexity of the position and the increasingly demanding job description have led many school superintendents and policy makers to think that only "supermen" or "wonder women" can fill the role (Pierce 2000). It is not surprising then to find a limited number of candidates willing to consider becoming a principal (Pounder and Merrill 2001b).

In discussing current trends in school leadership, Lashway (2006) asked, "Given the increased complexity of today's schools and the relentless demands for deep reform, are traditional definitions of the principal's role adequate, or must the job itself be redesigned?" (p. 20 ). Such calls to redefine the role of the principal, to make it a more manageable position, have led to proposals to distribute leadership across the organization. According to Spillane (2006), distributed leadership occurs when leadership functions are shared by a number of people in an organization or team and "leadership" emerges from the interactions within the group. The coprincipal leadership model, where two individuals share one leadership position, is a special case of distributing leadership (Gronn and Hamilton 2004).

Looking beyond the traditional solo principal to a co-principal model is not new. A proposal to restructure the principalship by dividing the role into two positions was first suggested by West (1978). He portrayed principals as a "beleaguered, bewildered and beat species" because of the increasing expectations and demands they were facing from school boards, superintendents, and teachers (p. 241). West thought the solution to these demands was to have two principals-one for instructional functions and one for administrative or 
managerial functions. As the Superintendent of the High Point Public Schools, High Point, North Carolina, West implemented a co-principal model that remained in place for 10 years, 1976-1986. Other school districts followed suit and co-principal teams were established in eight schools during that time period (Groover 1989; Korba 1982; Shockley and Smith 1981).

The participants in this study practiced two distinct forms of the co-principal leadership model. In both forms the power and authority of the principal were spread equally across two individuals. The most prevalent form occurred when two individuals each worked as full time principals, sharing the role and the position with equal authority (Eckman 2006; Grubb and Flessa 2006). The other form of the model occurred when two co-principals served part-time, dividing the days of the week they were each present and responsible for the school. The co-principals in this study made the decisions on how to divide the role of the principal. They separated the roles based on their individual strengths and interests rather than by focusing on administrative or instructional functions.

\section{Role dimensions: Role conflict and job satisfaction}

\section{Role conflict}

Role conflict occurs as individuals attempt to balance their family and home roles with their professional roles. Work-time studies indicate that dual-earner families and single-parent families are working longer hours and feeling more and more conflicted (Clarkberg and Moen 2001; Gerson and Jacobs 2001). Friedman et al. (2005) noted that conflicting demands of work and personal life have always been a part of the working world and that, historically, such role conflicts were resolved in favor of the employers (p. 97). Bailyn (2006) questioned that way of doing business and argued for "greater integration between the public domain of employment and the private domestic sphere" (p. 3).

Educational scholars have called for more reasonable parameters for the role of the principal, so that principals can manage the conflicts between their professional and personal lives (BorisSchacter and Langer 2006; Hurley 2001; Riehl and Byrd 1997). Kochan et al. (2000) found that the primary issue facing principals was 
"managing their work and their time and coping with the stresses, tasks and responsibilities of the job" (p. 305). According to assistant high school principals, who would be considered in the pipeline for principalships, one of the least attractive job characteristics of the role of principal is the difficulty they perceive principals have in balancing the demands of their work and families (Pounder and Merrill 2001b).

For the purpose of this study, role conflict, the endeavor of principals to balance their personal and family roles with their professional work, was measured with the Role Conflict Questionnaire (Nevill and Damico 1974). This questionnaire is a nine-item Likert-type scale where participants delineate their level of conflict from 1 (not at all conflicted) to 7 (extremely conflicted). The instrument includes questions relating to time for privacy, social commitments, and others; concerns over household management, finances, and child raising; and personal issues over expectations for self, others, and feelings of guilt. Total scores were computed as the average of the responses to these questions; higher scores on this instrument indicated a greater level of role conflict. Cronbach alphas for this instrument have ranged from .70 to .90 .

\section{Job satisfaction}

Job satisfaction is considered a desirable goal for all types of organizations because satisfied workers perform at higher levels than do those who are not satisfied (Chambers 1999). Studies of job satisfaction in the principalship have examined factors that contribute to both job satisfaction and dissatisfaction. Friesen et al. (1983) found the main sources of job satisfaction for principals to be their interpersonal relationships, achievements, responsibilities, and autonomy. The elements of the principalship found to be the most dissatisfying were amount of work, overall time constraints, parental attitudes, and general working conditions. Bacharach and Mitchell (1983) indicated that principals reported lower levels of job satisfaction because they felt overburdened by the role and its responsibilities. Similarly, Thompson et al. (1997) noted that the strongest predictors for decreased job satisfaction for principals were role ambiguity and role conflict.

A modified Job Satisfaction Survey (Eckman 2002; Mendenhall 1977; Schneider 1984) was used to measure job satisfaction in this study. This instrument included questions relating to community 
relations, working conditions, financial rewards, personal relationships, school characteristics, and career opportunities. Participants used a 4point Likert-type scale to indicate their degree of satisfaction from 1 (very dissatisfied)to 4 (very satisfied). Scores were computed as the average of the responses to these questions; higher scores reflect more job satisfaction. Eckman (2002) and Rice and Schneider (1994) reported the reliability co-efficient to be .90 .

\section{Data sources and methods}

This paper presents the findings from a secondary analysis of data collected in two studies on the principalship that focused on role conflict and job satisfaction (Eckman 2002, 2006). Data for the first study were obtained from traditional principals in three midwestern states of the United States. Data for the second study were obtained from female co-principals in schools throughout the United States.

Subjects for these studies were recruited from state departments of education, national principal associations, and Internet searches. This was necessary because there is no centralized database available that identifies school leaders by gender and organizational model. Survey packets for both of the studies, containing instruments measuring role conflict (Nevill and Damico 1974) and job satisfaction (Eckman 2002; Mendenhall 1977; Schneider 1984), as well as demographic questions, were sent to eligible participants. The return rates for the surveys of female traditional principals and co-principals were $69.2 \%$, and $51.2 \%$, respectively. Participants in the studies provided written comments regarding the aspects of the principalship they found both satisfying and dissatisfying. Additional information was requested from the co-principals regarding the reasons for implementation of the model, the type of co-principal model implemented, and their opinions on the strengths and weakness associated with the model used in their schools.

Fifty-one females participated in the co-principal study and 164 females participated in the traditional principal study. A random sample of 51 female traditional principals was selected from the traditional principal database to create groups of equal size. When comparing these 51 female traditional principals to the remainder of the group of female traditional principals, there were no significant differences in regard to role conflict $(t=1.056, d f=149, p=.293)$ and job satisfaction $(t=.207, d f=159, p=.836)$. 
NOT THE PUBLISHED VERSION; this is the author's final, peer-reviewed manuscript. The published version may be accessed by following the link in the citation at the bottom of the page.

\section{Findings}

\section{Personal and professional attributes}

The ages of the entire group of principals $(N=102)$ ranged from 28 to 74 years $(M=47.9, S D=9.5)$. The mean ages for the coprincipals and traditional principals were $49.1(S D=9.9)$ and $46.8(S D$ $=9.5)$, respectively. There were no significant differences between the co-principals and traditional principals in regard to age $(t=1.19, d f=$ $98, p=.238)$. Although $78 \%$ of the participants were married or partnered, there were significantly more married or partnered coprincipals than traditional principals $\left(x^{2}=6.68, d f=1, p=.014\right)$. Eighty-eight percent of the co-principals were married as compared to $68 \%$ of the traditional principals. Both groups reported having children; $85 \%$ of the traditional principals and $84 \%$ of the coprincipals. There was no significant difference between the groups in regard to having children $\left(x^{2}=0.012, d f=1, p=.91\right)$.

The respondents in this study were principals of private and public schools in urban, suburban, small cities and rural areas in the United States. Both the traditional principals and co-principals lead schools ranging in size from 26 to 4,500 students. To compare school size, based on student enrollments, the data were aggregated into four groups. These groups were created following criteria established by a Midwestern interscholastic athletic association for creating competitive athletic divisions: (1) 1-230 students; (2) 231-430 students; (3) 431930 students; and (4) 931 or more students. There were significantly more coprincipals leading moderately larger schools than traditional principals $\left(x^{2}=10.05, d f=3, p=.018\right)$. Twenty-six percent of the traditional principals lead schools with 431-930 students as compared to $46 \%$ of the co-principals (Table 1 ).

\section{Role conflict}

The responses to the nine role conflict questions are presented for the entire group $(N=102)$ in Table 2 . The areas with the most role conflict were time for privacy, time for social commitments, and conflicts regarding expectations for self. The participants indicated being the least conflicted in regard to concerns over how money was spent in the family (financial concerns).

In regard to the total role conflict score, the co-principals had significantly lower levels of role conflict $(M=3.35, S D=1.27)$ than 
the traditional principals $(M=3.92, S D=1.01), t=2.49, d f=100, p$ $=.015, \mathrm{~g} 2=.061$. To further explore role conflict, an item analysis of the role conflict questions was performed (Table 3 ). Traditional principals had significantly higher levels of role conflict in regard to time for social commitments, household management, child raising and feelings of guilt than the co-principals.

One traditional principal explained the role conflicts that occur between personal and professional lives; "The greatest area of conflict is not so much with my spouse but on my own expectations of what I want to be as a wife and a mother. There is a large amount of stress associated with the position of principal. The stress can sap you of the emotional energies needed to raise a family. I see so many needy kids due to lack of parental involvement; I don't want my kids to be in that same category. Balance is a difficult thing to achieve." Another traditional principal commented that her long days and weeks created conflicts, "I work $70 \mathrm{~h}$ every week. It's a minimum of a $12 \mathrm{~h}$ day and very often $15 \mathrm{~h}$ and it's another $8 \mathrm{~h}$ on the weekends". Several commented about their concerns over their health as they tried to find a balance for their work and personal lives. As one participant wrote, "If I had to do this for a long, long time, I think that it would definitely have a more detrimental effect on my health."

Several of the co-principals noted that being a co-principal had alleviated some of the conflicts between personal and professional lives. With a co-principal team workloads can be balanced, responsibilities divided and attendance at meetings and after school activities shared. One co-principal acknowledged that participating in the model had allowed her to be home with her young children. Another explained that, because she was a co-principal, she could continue working even while she was caring for an elderly parent.

\section{Job satisfaction}

In addition to the total score, the Job Satisfaction Survey is composed of nine subscales (Schneider 1984): (1) working relations with other administrators; (2) relations with co-workers; (3) career and professional growth opportunities; (4) school reputation and goals; (5) financial rewards; (6) working conditions; (7) amount of work; (8) meeting students needs; and (9) parental and community involvement with school. The areas in which the entire group ( $N=$ 102) expressed the highest level of job satisfaction were school

Journal of Educational Change, Vol. 11, No. 3 (August 2010): pg. 205-219. DOI. This article is @ Springer and permission has been granted for this version to appear in e-Publications@Marquette. Springer does not grant permission for this article to be further copied/distributed or hosted elsewhere without the express permission from Springer. 
reputation and goals, relations with co-workers, career and professional growth opportunities, and working relations with other administrators (Table 4).

When comparing the total job satisfaction score, the coprincipals experienced significantly higher levels of job satisfaction ( $M$ $=3.05, S D=.40)$ than the traditional principals $(M=2.82, S D=.37)$, $t=2.96, d f=100, p=.004, \eta^{2}=.081$. In regard to the job satisfaction subscales, the co-principals were significantly more satisfied than the traditional principals in the areas of school reputation and goals, relations with co-workers, career and professional growth opportunities, meeting student needs and financial rewards (Table 5 ). The traditional principals and co-principals both indicated the least satisfaction on the subscale of financial rewards. This subscale included questions regarding the amount of money they made and the compensation package in their school district.

Co-principals in the study commented that a factor that contributed to their satisfaction in their positions was that they were never alone, they shared in decision-making, and there was always one principal on site. As one co-principal explained, "The most stressful aspects of the principalship are shared (i.e., discipline, parent issues, teacher supervision and evaluations) which prevents burnout." Another participant noted that the co-principalship was satisfying because with someone with whom to share the job, she now had time "to deal with the academic and administrative aspects of being a principal and to focus on being an educational leader." Several commented that the position was one of the best experiences of their careers. One wrote, "I love the arrangement and if I choose to move on in my career I would like to have the opportunity to do this again."

\section{Correlations}

In order to examine the relationship of the demographic characteristics of school size, marital status, presence of children at home, and age in relationship to role conflict and job satisfaction, Pearson Product Moment Correlations were computed. There were no significant bivariate relations based on school size, children at home and marital status. Age was the only measure that was significantly correlated to role conflict and job satisfaction. The older the respondent, the less role conflict experienced $(r=-.33, p=.001)$, and the higher the levels of job satisfaction $(r=.26, p=.008)$. 
Not surprisingly, there was a statistically significant correlation of role conflict with job satisfaction for the group. As role conflict increased for these principals $(N=102)$, job satisfaction decreased ( $r$ $=-.48, p<.01)$. A partial correlation coefficient was computed to examine the influence of age on the relationship of job satisfaction and role conflict. The relationship was unchanged; the partial correlation coefficient was $r=-.480, d f=93, p<.0005$.

To control for the influence of age, an analysis of co-variance was performed comparing the levels of job satisfaction and role conflict between the traditional principals and co-principals. After adjusting for age, there was a significant difference in role conflict between the traditional principals (Adjusted $M=3.89$, SEM $=.155$ ) and coprincipals (Adjusted $M=3.42, S E M=.161$ ), $F(1,93)=4.37, p=.039, \eta^{2}$ $=.045$. The traditional principals experienced significantly more role conflict than did the co-principals. Similarly, there was a significant difference in job satisfaction between traditional principals (Adjusted $M$ $=2.83, S E M=.053$ ) and co-principals (Adjusted $M=3.03, S E M=.053$ ), $F(1,97)=7.05, p=.009, \eta^{2}=.068$. The co-principals experienced higher levels of job satisfaction than did the traditional principals.

There was a significant difference in school size between traditional principals and co-principals. Therefore, a regression analysis was performed to examine the impact of type of leadership model (traditional or co-principal) on role conflict. After adjusting for school size, the type of leadership model (traditional or coprincipal) significantly explained $6 \%$ of the variance with the entire model explaining a total of $8 \%$ of the variance in role conflict (Table 6 ). Similarly, a regression analysis was performed to examine the impact of type of leadership model on job satisfaction. After adjusting for school size, the type of leadership model (traditional or co-principal) significantly explained $9.1 \%$ of the variance with the regression model explaining a total of $11 \%$ of the variance in job satisfaction. Coprincipals had lower levels of role conflict and higher levels of job satisfaction than did traditional principals after adjusting for school size.

\section{Discussion and conclusion}

The position of school principal is increasingly difficult, time consuming and generally unattractive to prospective applicants (Court 2003; Thomson and Blackmore 2006; NCLS 2006). Due to the fact

Journal of Educational Change, Vol. 11, No. 3 (August 2010): pg. 205-219. DOI. This article is (C) Springer and permission has been granted for this version to appear in e-Publications@Marquette. Springer does not grant permission for this article to be further copied/distributed or hosted elsewhere without the express permission from Springer. 
that the work of the principal is so demanding, consuming so much time, and never completed, Gronn (2003) characterizes the role as "greedy work." The co-principal model has been proposed as one solution to the onerous time demands of the principalship. Indeed it has been implemented in schools of all sizes and types, in cities, suburbs and rural areas in several different countries. Before asserting that the co-principal model provides the necessary redesign of the principalship that addresses issues of work intensification and role unattractiveness, the model needs to be studied more closely for both female and male leaders. In this paper, we compared the levels of role conflict and job satisfaction experienced by female co-principals to the levels experienced by female traditional principals as a way to examine the effect of the co-principal leadership model.

Traditional principals in this study reported more role conflict in their personal lives than did the co-principals. One participant expressed quite clearly the role conflicts she currently faced as a principal and the reasons why she delayed becoming a traditional principal, "Being away from home and doing all these things and being everything to everybody except your own children or family is something that moves a lot of professionals ahead. I wasn't willing to do that at the time that I had children at home." In contrast, coprincipals indicated that they had less role conflict because they were able to balance their personal and professional lives. With two individuals handling the demands of the principalship, the co-principals experienced less feelings of guilt than did the traditional principals as "each co-principal had time to spend with their own families" (Thomson and Blackmore 2006, p. 169).

The co-principals in this study reported higher levels of job satisfaction than did the traditional principals. Co-principals were more satisfied than the traditional principals with their ability to meet students' needs, have relationships with coworkers, engage in career and professional growth opportunities, and experience pride in their schools' reputation and goals. The co-principal model provided these principals with time to interact and develop relationships with their teachers, students, and co-workers. They were available for both formal and informal meetings and could engage with these groups in meaningful ways. In the coprincipal model there is always another principal to "cover" the school, enabling each co-principal to attend conferences and workshops that provide personal and professional 
growth. Finally, with two leaders, it is possible for each co-principal to be aware of what is going on in the school and for one principal to be present at all school functions. Indeed, co-principals have time to participate in the activities of their schools without feeling overwhelmed.

For the entire group in this study, financial compensation was the lowest subscale on the job satisfaction instrument. Inadequate or insufficient compensation for principals has been identified as a source of dissatisfaction; the financial rewards are not commensurate with the enormous responsibilities of the position (Whitaker 2001). There was no standard method used by schools to determine the salary level for co-principals. Some of the co-principals reported being placed on the salary scale mid-point between the salary of an assistant principal and principal. Other coprincipals were paid at the same rate as were traditional principals. The level of compensation needs to be addressed for both traditional principals and co-principals.

As the size of a school increases, so does the magnitude of instructional and management issues. Having larger student populations increases the complexity of the role of the principal because there are more students, teachers, staff and parents for whom the principal is responsible. The National College of School Leadership (2006) reported that the aspects of the principalship considered most satisfying by principals were helping students to succeed academically and encouraging faculty to develop professionally. With larger student enrollments, there is less opportunity for traditional principals to interact with their students and faculties. The co-principal model appears to be a viable option to address this issue. With two principals sharing the workload and the responsibilities each has more time to devote to working with students and staff.

There are positives and negative aspects to both leadership models (traditional and co-principal). The traditional principal has historically been characterized as being "lonely at the top" as all of the decision making on instructional and managerial issues is in his/her hands (Jackson 1977). In contrast co-principals, who share authority and responsibilities, making decisions together as a team, report not feeling isolated or "lonely at the top". Several of the co-principals in this study acknowledged that there are difficulties in the sharing of power and leadership. A solo decision-maker does not have to spend 
the time and effort consulting and compromising, as does a coprincipal. However, the co-principals maintained that the benefits of their co-principalships offset any difficulties that occurred when two leaders must develop and maintain working relationships as they divide job responsibilities and share decision-making. One co-principal was emphatic about the strengths of the model; "Imagine two administrators, passionate, knowledgeable and energetic, philosophically aligned and working on school improvement in concert, all the while having each other to strategize with, share failures and successes with, and to grow with."

The co-principal model also has the potential to attract female aspirants. First and foremost, the model increases the total number of principal positions available. By providing more positions and more shared leadership and mentorships, the coprincipal model may serve as an avenue for addressing the continued under-representation of women in principal positions (Young and McLeod 2001). There is the likelihood that women will be interested in the co-principalship, as the role appears more manageable and therefore more satisfying than the traditional principalship. Additionally, in a co-principalship, experienced female principals find they can maintain their leadership positions when they face changing family demands, such as child rearing or caring for elderly parents. One co-principal in this study explained, "I can't imagine having stepped up to lead at my school if I had had to do it alone." Another noted that her co-principal provided the mentorship and encouragement she needed as she honed her leadership skills.

A limitation of this study is that the data for the two groups were collected sequentially. Although the data were not collected simultaneously, there were no significant changes in the United States that would have directly influenced the participants' job satisfaction or role conflict during these years. School principals continued to face increasingly complex demands over this time period. An additional limitation, as in all survey research, is the possibility of a self-selection bias. Possibly those that did not respond differ in some way from the respondents in both the traditional and co-principal models. Finally, although the co-principal model is in practice in schools internationally, the participants in this study were principals and co-principals in schools within the United States.

Journal of Educational Change, Vol. 11, No. 3 (August 2010): pg. 205-219. DOI. This article is @ Springer and permission has been granted for this version to appear in e-Publications@Marquette. Springer does not grant permission for this article to be further copied/distributed or hosted elsewhere without the express permission from Springer 
The co-principal model has "significantly shifted one of the major problems of the principalship namely the intensity of the work, and the resulting lack of private 'down time"' (Thomson and Blackmore 2006, p. 169). With two leaders in a coprincipal team, the model offers an organizational structure that allows for increased interactions between leaders, teachers, parents, students, and community groups. Examining the effect of the co-principal model on students, teachers, parents and community members is the next necessary step in understanding and evaluating this leadership model. The information gained will assist school administrators in their decision to consider a co-principal model. Identifying the attributes that make for successful co-leadership teams and how to make the model sustainable over time will aid schools in the implementation of a co-principal model as an alternative to the traditional solo principal.

\section{References}

Association of California School Administrators. (2001, June). Recruitment and retention of school leaders: A critical state need. Retrieved March 10, 2007, from http://www.acsa.org/publications.

Bacharach, S., \& Mitchell, S. (1983). The sources of dissatisfaction in educational administration: A role-specific analysis. Educational Administration Quarterly, 19(1), 101-128. doi:10.1177/0013161X 83019001006.

Bailyn, L. (2006). Breaking the mold: Redesigning work for productive and satisfying lives. Ithaca, NY: Cornell University Press.

Bell, C., \& Chase, S. (1993). The underrepresentation of women in school leadership. In C. Marshall (Ed.), The new politics of race and gender (pp. 141-154). London: Falmer.

Boris-Schacter, S., \& Langer, S. (2006). Balanced leadership: How effective principals manage their work. New York: Teachers College Press.

Bunnell, T. (2008). The Yew Chung model of dual culture co-principalship: A unique form of distributed leadership. International Journal of Leadership in Education, iFirst article, 1-20.

Chambers, J. (1999). The job satisfaction of managerial and executive women: Revisiting the assumptions. Journal of Education for Business, $75(2), 69-74$.

Chirichello, M. (2003). Reinventing the principalship: From centrist to collective leadership. In F. Lunenburg \& C. Carr (Eds.), Shaping the future: Policy, partnership and emerging perspectives. Oxford, UK: Scarecrow Education.

Journal of Educational Change, Vol. 11, No. 3 (August 2010): pg. 205-219. DOI. This article is @ Springer and permission has been granted for this version to appear in e-Publications@Marquette. Springer does not grant permission for this article to be further copied/distributed or hosted elsewhere without the express permission from Springer. 
NOT THE PUBLISHED VERSION; this is the author's final, peer-reviewed manuscript. The published version may be

accessed by following the link in the citation at the bottom of the page.

Clarkberg, M., \& Moen, P. (2001). Understanding the time-squeeze: Married couples' preferred and actual work-hour strategies. The American Behavioral Scientist, 44(7), 1115-1136.

Court, M. (2003). Different approaches to sharing school leadership. Research Associate Reports, National College for School Leadership. Retrieved from http://www.ncsl.org.uk/researchassociates/.

DiPaola, M., \& Tschannen-Moran, M. (2003). The principalship at a crossroads: A study of the conditions and concerns of principals. National Association of Secondary School Principals Bulletin, 87(634), 43-65.

Eckman, E. (2002). Women high school principals: Perspectives on role conflict, role commitment and job satisfaction. Journal of School Leadership, 12(1), 57-77.

Eckman, E. (2006). Co-principals: Characteristics of dual leadership teams. Leadership and Policy in Schools, 5(2), 89-107. doi: $10.1080 / 15700760600549596$.

Educational Research Service. (1998). Is there a shortage of candidates for the job of school principal? National Association of Secondary School Principals and National Association of Elementary School Principals. Retrieved June 7, 2007, from http://www.principals.org/.

Ferrandino, V., \& Tirozzi, G. (2000, March 22). The principal, keystone of a high-achieving school: Attracting and keeping the leaders we need. Education Week, 19(28).

Friedman, A., Christensen, P., \& Degroot, J. (2005). Work and life: The end of the zero-sum game. In Harvard business review on women in business (pp. 95-123). Cambridge, MA: Harvard Business School Publishing Corp.

Friesen, D., Holdaway, E., \& Rice, A. (1983). Satisfaction of school principals and their work. Educational Administration Quarterly, 19(4), 35-58. doi:10.1177/0013161X83019004003.

Gerson, K., \& Jacobs, J. (2001). Changing the structure and culture of work: Work and family conflict, work flexibility, and gender equity in the modern workplace. In $R$. Hertz \& $N$. Marshall (Eds.), Working families: The transformation of the American home (pp. 207-226). Berkeley, CA: University of California Press.

Grogan, M. (1999). Equity/equality issues of gender, race, and class. Educational Administration Quarterly, 35(4), 518-536. doi: $10.1177 / 00131619921968743$.

Gronn, P. (2003). The new work of educational leaders: Changing leadership practice in an era of school reform. Thousand Oaks, CA: SAGE Publications.

Journal of Educational Change, Vol. 11, No. 3 (August 2010): pg. 205-219. DOI. This article is @ Springer and permission has been granted for this version to appear in e-Publications@Marquette. Springer does not grant permission for this article to be further copied/distributed or hosted elsewhere without the express permission from Springer. 
Gronn, P., \& Hamilton, A. (2004). "A bit more life in the leadership": Coprincipalship as distributed leadership practice. Leadership and Policy in Schools, 3(1), 3-35. doi:10.1076/Ipos.3.1.3.27842.

Groover, E. C. (1989). Perceptions of the co-principalship as implemented in High Point, North Carolina (Unpublished doctoral dissertation, University of North Carolina, Greensboro).

Grubb, W. N., \& Flessa, J. (2006). "A job too big for one": Multiple principals and other non-traditional approaches to school leadership. Educational Administration Quarterly, 42(4), 518-559. doi:10.1177/ $0013161 \times 06290641$.

Houston, P. (1998). The ABC's of administrative changes. Education Week, $17(38), 32-44$.

Hurley, J. (2001). The principalship: Less may be more. Education Week, 20(37), 37-39.

Institute of Educational Leadership. (2000, October). Leadership for student learning: Reinventing the principalship. A Report of the Task Force on the Principalship. Washington, DC: IEL.

Jackson, P. W. (1977). Lonely at the top: Observations on the genesis of administrative isolation. The School Review, 85(3), 425-432. doi: $10.1086 / 443351$.

Klenke, K. (1996). Women and leadership: A contextual perspective. New York, NY: Springer Publishing Co.

Kochan, F., Spencer, W., \& Mathews, J. (2000). Gender-based perceptions of the challenges, changes, and essential skills of the principalship. Journal of School Leadership, 10(4), 290-310.

Korba, W. (1982). The co-principal plan: Some insights and some cautions. NASSP Bulletin, 66(456), 57-63. doi:10.1177/019263658206645610.

Lashway, L. (2006). The landscape of school leadership. In S. Smith \& P. Piele (Eds.), School leadership: Handbook for excellence in student learning (4th ed., pp. 18-37). Thousand Oaks, CA: Corwin Press.

Leithwood, K., \& Duke, D. (1999). A century's quest to understand school leadership. In J. Murphy \& K. Seashore Louis (Eds.), Handbook of research on educational administration (2nd ed., pp. 45-72). San Francisco: Jossey-Bass.

Matthews, L. J., \& Crow, G. M. (2003). Being and becoming a principal: Role conceptions for contemporary principals and assistant principals. New York: Pearson Educational, Inc.

Mendenhall, D. R. (1977). Relationship of organizational structure and leadership behavior to teacher job satisfaction in IGE schools (Tech. Rep. No. 412). Madison: Wisconsin Research and Development Center for Cognitive Learning.

Journal of Educational Change, Vol. 11, No. 3 (August 2010): pg. 205-219. DOI. This article is (C) Springer and permission has been granted for this version to appear in e-Publications@Marquette. Springer does not grant permission for this article to be further copied/distributed or hosted elsewhere without the express permission from Springer. 
National Association of Secondary School Principals. (2001, November). News release: Priorities and barriers in high school leaderships. Retrieved from http://www.principals.org/.

National College of School Leadership. (2006). What we know about school leadership. Retrieved from http://www.ncls.org.uk.

Nevill, D., \& Damico, S. (1974). Development of a role conflict questionnaire for women: Some preliminary findings. Journal of Consulting and Clinical Psychology, 42(5), 743. doi:10.1037/ h0037052.

Paterson, F. (2006). New models of headship: Co-headship. National College for School Leadership. Retrieved from http://www.ncsl.org.uk/publications.

Pierce, M. (2000). Portrait of the 'Super Principal'. Harvard Education Letter Research Online. Retrieved July 23, 2004, from http://www.edletter.org/past/issues/2000-so/principal.shtml/.

Pounder, D., \& Merrill, R. (2001a). Job desirability of the high school principalship: A job choice theory perspective. Educational Administration Quarterly, 37(1), 27-57.

Pounder, D., \& Merrill, R. (2001b). Redesigning the principalship could have a positive impact on the pipeline supply. School Administrator, 58(10), 18-21.

Protheroe, N. (2001). Attracting and retaining high quality people for the principalship: Problems and possibilities. Paper presented at the annual meeting of the American Educational Research Association, Seattle, WA.

Rice, E. M., \& Schneider, G. T. (1994). A decade of teacher empowerment: An empirical analysis of teacher involvement in decision-making, 19801991. Journal of Educational Administration, 31(1), 43-58. doi: $10.1108 / 09578239410051844$

Riehl, C., \& Byrd, M. (1997). Gender differences among new recruits to school administration: Cautionary footnotes to an optimistic tale. Educational Evaluation and Policy Analysis, 19(1), 45-64.

Schneider, G. T. (1984). Teacher involvement in decision-making: Zones of acceptance, decision conditions, and job satisfaction. Journal of Research and Development in Education, 18(1), 25-32.

Sergiovanni, T. (2001). The principalship: A reflective practice perspective. Boston, MA: Allyn \& Bacon.

Shockley, R., \& Smith, D. (1981). The co-principal: Looking at realities. The Clearing House: A Journal for Modern Junior and Senior High Schools, $55,90-93$.

Spillane, J. (2006). Distributed leadership. San Francisco, CA: Jossey-Bass.

Strike, K. A. (2005). The ethics of school administration. New York: Teachers College Press.

Journal of Educational Change, Vol. 11, No. 3 (August 2010): pg. 205-219. DOI. This article is (C) Springer and permission has been granted for this version to appear in e-Publications@Marquette. Springer does not grant permission for this article to be further copied/distributed or hosted elsewhere without the express permission from Springer. 
NOT THE PUBLISHED VERSION; this is the author's final, peer-reviewed manuscript. The published version may be accessed by following the link in the citation at the bottom of the page.

Thompson, D., McNamara, J., \& Hoyle, J. (1997). Job satisfaction in educational organizations: A synthesis of research findings. Educational Administration Quarterly, 33(1), 7-37. doi:10.1177/ 0013161 X97033001002.

Thomson, P., \& Blackmore, J. (2006). Beyond the power of one: Redesigning the work of school principals. Journal of Educational Change, 7, 161177. doi:10.1007/s10833-006-0003-6.

West, E. (1978). The co-principalship: Administrative realism. High School Journal, 61, 124-246.

Whitaker, K. (2001). Where are the principal candidates? Perceptions of superintendents. NASSP Bulletin, 85(625), 82-92. doi: $10.1177 / 019263650108562509$.

Young, M., \& McLeod, S. (2001). Flukes, opportunities, and planned interventions: Factors affecting women's decisions to become school administrators. Educational Administration Quarterly, 37(4), 462-502.

\section{Appendix}

Table 1: Percent of traditional and co-principals based on school size (number of students enrolled), $N=102$

\begin{tabular}{llll}
\hline School size & $\begin{array}{l}\text { Traditional principals } \\
(\%)(n=51)\end{array}$ & $\begin{array}{l}\text { Co-principals }(\%)(n= \\
51)\end{array}$ & Total (\%) \\
\hline Less than 230 & 37.3 & 12 & 24.8 \\
$231-430$ & 15.7 & 22 & 18.8 \\
$431-930$ & 25.5 & 46 & 35.6 \\
931 and more & 21.6 & 20 & 20.8 \\
\hline
\end{tabular}

$X^{2}(3, N=102)=10.05, p=.018$

Journal of Educational Change, Vol. 11, No. 3 (August 2010): pg. 205-219. DOI. This article is @ Springer and permission has been granted for this version to appear in e-Publications@Marquette. Springer does not grant permission for this article to be further copied/distributed or hosted elsewhere without the express permission from Springer. 
NOT THE PUBLISHED VERSION; this is the author's final, peer-reviewed manuscript. The published version may be accessed by following the link in the citation at the bottom of the page.

Table 2: Role conflict questions

\begin{tabular}{lll}
\hline & $M$ & $S D$ \\
\hline Time for privacy & 4.69 & 1.70 \\
Time for social commitments & 4.61 & 1.68 \\
Conflicts regarding expectations for self & 4.11 & 1.83 \\
Feelings of guilt & 3.80 & 1.71 \\
Time for child raising & 3.61 & 1.98 \\
Meeting expectations of others & 3.50 & 1.55 \\
Time for household management & 3.41 & 1.77 \\
Time for significant other & 2.79 & 1.81 \\
Financial concerns & 2.34 & 1.59 \\
\hline
\end{tabular}

$(N=102)$. Scale: 1 not at all, 7 extremely

Table 3: Role conflict questions: Comparisons of traditional principals and co-principals

\begin{tabular}{llll}
\hline & $\begin{array}{l}\text { Traditional } \\
\text { principals } M \\
(S D)(n=51)\end{array}$ & $\begin{array}{l}\text { Co-principals } M \\
(S D)(n=51)\end{array}$ & $t, p$ \\
\hline Time for privacy & $4.78(1.55)$ & $4.59(1.86)$ & $t=.56, p=.58$ \\
$\begin{array}{l}\text { Time for social commitments* } \\
\text { Conflicts regarding expectations }\end{array}$ & $5.00(1.4)$ & $4.22(1.86)$ & $t=2.34, p=.02$ \\
for self & $4.43)$ & $3.78(1.69)$ & $t=.1 .81, p=.073$ \\
$\begin{array}{l}\text { Feelings of guilt* } \\
\text { Time for child raising* }\end{array}$ & $4.22(1.6)$ & $3.35(1.72)$ & $t=2.58, p=.011$ \\
$\begin{array}{l}\text { Meeting expectations of others } \\
\text { Time for household }\end{array}$ & $3.69(1.63)$ & $3.30(1.44)$ & $t=2.19, p=.032$ \\
management* & $3.88(1.61)$ & $2.92(1.82)$ & $t=2.24, p=.216$ \\
Time for significant other & $3.02(1.91)$ & $2.55(1.70)$ & $t=1.29, p=.201$ \\
Financial concerns & $2.35(1.45)$ & $2.33(1.74)$ & $t=.064, p=.950$ \\
\hline
\end{tabular}

Scale: 1 not at all, 7 extremely

${ }^{\star} P<.05$ 
NOT THE PUBLISHED VERSION; this is the author's final, peer-reviewed manuscript. The published version may be accessed by following the link in the citation at the bottom of the page.

Table 4: Job satisfaction subscales

\begin{tabular}{lll}
\hline & $M$ & SD \\
\hline School reputation \& goals & 3.22 & 0.48 \\
Relations with coworkers & 3.21 & 0.46 \\
Career \& professional growth opportunities & 3.11 & 0.56 \\
Working relations with other administrators & 3.00 & 0.75 \\
Meeting student needs & 2.99 & 0.49 \\
Amount of work & 2.84 & 0.51 \\
Working conditions & 2.79 & 0.74 \\
Parental \& community involvement & 2.69 & 0.59 \\
Financial rewards & 2.65 & 0.63
\end{tabular}

$(N=102)$. Scale: 1 not at all, 7 extremely

Table 5: Comparison of job satisfaction subscales

\begin{tabular}{|c|c|c|c|}
\hline & $\begin{array}{l}\text { Traditional } \\
\text { principals } M \\
(S D)(n=51)\end{array}$ & $\begin{array}{l}\text { Co-principals } M \\
(S D)(n=51)\end{array}$ & $t, p$ \\
\hline School reputation \& goals* & $3.11(.41)$ & $3.33(.53)$ & $t=2.33, p=.022$ \\
\hline Relations with coworkers ${ }^{\star}$ & $3.10(.49)$ & $3.31(.42)$ & $t=2.32, p=.022$ \\
\hline $\begin{array}{l}\text { Career \& professional growth } \\
\text { opportunities* }\end{array}$ & $2.88(.52)$ & $3.35(.50)$ & $t=4.59, p<.0005$ \\
\hline $\begin{array}{l}\text { Working relations with other } \\
\text { administrators }\end{array}$ & $2.92(.78)$ & $3.07(.70)$ & $t=.99, p=.322$ \\
\hline Meeting student needs* & $2.90(.49)$ & $3.09(.47)$ & $t=2.06, p=.042$ \\
\hline Amount of work & $2.78(.49)$ & $2.90(.53)$ & $t=1.10, p=.274$ \\
\hline Working conditions & $2.66(.72)$ & $2.92(.74)$ & $t=1.76, p=.082$ \\
\hline $\begin{array}{l}\text { Parental \& community } \\
\text { involvement }\end{array}$ & $2.60(.53)$ & $2.76(.64)$ & $t=1.35, p=.180$ \\
\hline Financial rewards ${ }^{*}$ & $2.51(.68)$ & $2.79(.54)$ & $t=2.26, p=.026$ \\
\hline
\end{tabular}

$(N=102)$. Scale: 1 very dissatisfied, 7 very satisfied

$* P<.05$

Journal of Educational Change, Vol. 11, No. 3 (August 2010): pg. 205-219. DOI. This article is @ Springer and permission has been granted for this version to appear in e-Publications@Marquette. Springer does not grant permission for this article to be further copied/distributed or hosted elsewhere without the express permission from Springer. 
NOT THE PUBLISHED VERSION; this is the author's final, peer-reviewed manuscript. The published version may be accessed by following the link in the citation at the bottom of the page.

Table 6: Regression analyses of job satisfaction and role conflict with leadership type

\begin{tabular}{|c|c|c|c|c|c|c|}
\hline & \multicolumn{3}{|c|}{ Job satisfaction } & \multicolumn{3}{|c|}{ Role conflict } \\
\hline & $\beta$ & $t$ & $p$ & $\beta$ & $t$ & $p$ \\
\hline School size & .152 & 1.58 & .117 & -.155 & .98 & .331 \\
\hline \multirow[t]{2}{*}{ Leadership type } & .280 & 2.93 & .004 & -.220 & 2.25 & .027 \\
\hline & \multicolumn{3}{|c|}{$F(2,98)=6.03, p=.003$} & \multicolumn{3}{|c|}{$F(1,99)=4.19, p=.018$} \\
\hline
\end{tabular}

Note: School size groups: $1<230,2231-430,3431-930,4 \geq 931$

Leadership type: 1 traditional principal, 2 co-principal 